\title{
Orbital filariasis in a Nigerian Community
}

Wilson IB Onuigbo*

Department of Pathology, Medical Foundation \& Clinic, Nigeria

*Corresponding author: Wilson IB Onuigbo, Department of Pathology, Medical Foundation \& Clinic, Enugu 400001.

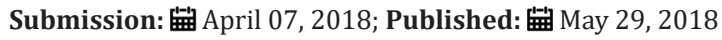

\begin{abstract}
Filariasis is a worldwide zoonotic infection. Recent reports concerning the orbit have come from several countries. Therefore, a Nigerian report is deemed to be worthy of documentation.
\end{abstract}

Keywords: Orbit; Filariasis; Worldwide; Nigeria

\section{Introduction}

Ocular filariasis is an interesting infestation. Recent reports appeared in alphabetical order in Bangladesh [1], India [2-4],
Iran [5] and USA [6]. Therefore, a Nigerian report is deemed to be worthy of documentation especially in tabular form.

\section{Result}

(Table 1).

Table 1: Epidemiological data on orbital filariasis.

\begin{tabular}{|c|c|c|c|c|c|c|c|}
\hline No & Initials & Age & Sex & Side & Site & Size & Diagnosis \\
\hline 1 & UP & 29 & F & L & Conjunctiva & Fragment & Melanoma \\
\hline 2 & KI & 35 & M & R & Conjunctiva & 0.5 cm piece & Granuloma \\
\hline 3 & OL & 40 & M & L & Conjunctiva & Tiny frags & Melanoma \\
\hline 4 & AL & 66 & M & L & Conjunctiva & Tiny piece & Neoplasm \\
\hline 5 & KO & 25 & M & L & Eyelid & $1.2 \mathrm{~cm}$ & Onchocerciasis \\
\hline
\end{tabular}

\section{Discussion}

Most reports are of single cases [1-5]. Here, as many as 5 cases are being considered. Only one of them was rightly diagnosed, i.e., onchocerciasis. Some data stand out. Thus, males preponderated as did the left side. The 25 to 66 range in years (means 39 years) compares with the literature range of 11 to 40 years (means 28 years). One local case was situated in the eyelid. This was true of the report from Bangladesh [1]. As might be expected, the biopsy specimen was substantial. In contrast, concerning the conjunctiva, tiny materials alone were submitted for analysis which were enough to reveal the filarial worms.

Of course, the local examples differ from the USA picture [6]. In this context, in that country, the scenery was painted as follows: "Several factors acting in concert now place US residents, returning travelers, and expatriates at risks of contracting ocular filariasis including increasing seroprevalence rates of zoonotic filariasis."

\section{References}

1. Kadir M, Jahan F, Quadir ASMM, Rahman (2015) Filariasis of the eyelid subcutaneous manifestation in Bangladesh. Indian J Clin Exp Ophthalmol 1(3): 184-186.

2. Ganesh SK, Babu K, Krishnakumar S, Biswas J (2003) Ocular filariasis due to Wuchereria bancrofti presenting as panuveitis: A case report. Ocul Immunol Inflamm 11(2): 145-148.

3. Rautaraya B, Tiwari S, Mahapatra A, Nanda A (2011) Ocular filariasis. Trop Parasitol 1(2): 116-118.

4. Smitha M, Rajendran VR, Devarajan E, Anitha PM (2008) Case report: Orbital dirofilariasis. Indian J Radiol Imaging 18(1): 60-62.

5. Tavakolizadeh S, Mobedi I (2009) Orbital dirofilairasis in Iran: A case report. Korean J Parasitol 47(4): 397-399.

6. Diaz JH (2015) Ocular filariasis in US residents, returning travelers, and expatriates. J La State Med Soc 167(4): 172-176. 
(c) (i) Creative Commons Attribution 4.0 International License

For possible submissions Click Here

Submit Article

\section{MSOR Medical 8 \\ Medical \& Surgical Ophthalmology Research} Ophthalmolo
Research Benefits of Publishing with us

- High-level peer review and editorial services

- Freely accessible online immediately upon publication

- Authors retain the copyright to their work

- Licensing it under a Creative Commons license

- Visibility through different online platforms 